\title{
Penguatan solidaritas sosial komunitas petani bawang merah Di desa serading kecamatan moyo hilir
}

\author{
Sumitro $^{1}$, Edy Kurniawansyah ${ }^{2}$ \\ ${ }^{1,2}$ Institut Ilmu Sosial dan Ilmu Budaya Samawa Rea \\ E-mail: sumitro765@gmail.com, almusukyedy@gmail.com
}

\begin{abstract}
Abstrak. Riset ini mendeskripsikan kondisi solidaritas sosial dalam komunitas petani, penelitian ini berpeluang pula menjadi model pemberdayaan untuk komunitas petani ke depannya. Tujuan penelitian ini adalah untuk mendeskripsikan a.) Bentuk penguatan solidaritas komunitas petani bawang merah di Desa Serading Kecamatan Moyo Hilir, dan mendeskripsikan faktor-faktor apakah yang mendukung penguatan solidaritas komunitas petani tersebut. Jenis penelitian yang digunakan adalah kualitatif dengan desain etnografi. Tempat penelitian di Desa Serading Kecamatan Moyo Hilir Kabupeten Sumbawa. Waktu penelitian mulai bulan Januari sampai Mei 2020. Subjek penelitian Komunitas petani penggarap asal Bima yang bekerja di lokasi penelitian. Teknik pengumpulan data menggunakan observasi, wawancara dan dokumentasi. Keabsahan data menggunakan triangulasi sumber. Teknik analisis data dengan pengumpulan data, reduksi data, penyajian data, dan kesimpulan. Adapun hasil penelitian ini berupa, 1.) Bentuk penguatan yang terjadi dalam solidaritas sosial komunitas petani di Desa Serading, terdiri dari: a.) Gotong royong dan b.) Kerja sama (individu dengan individu atau kelompok dengan kelompok). Selanjutnya, Faktor - faktor penguat solidaritas sosial di Desa serading diantaranya: a.) Faktor Ekonomi dimana motif-motif dari solidaritas sosial yang muncul kebanyakan berupa usaha peningkatan taraf ekonomi petani; b.) Faktor Agama, Petani di Desa Serading mayoritas beragama Islam. meskipun mayoritas petani di Desa Serading merupakan pendatang dari berbagai daerah lain, namun menemukan petani penggarap yang beragama lain selain Islam menjadi hal yang sulit; c.) Faktor Budaya, menarik dari temuan lapangan, mayoritas petani penggarap di desa Serading berasal dari Bima. Salah faktornya adalah ada kemiripan budaya (baik bentuknya maupun nilai budayanya) antara masayarakat Bima dan masyarakat Sumbawa.
\end{abstract}

\section{Kata Kunci: Penguatan, Solidaritas Sosial, Komunitas Petani}

Abstract. This research describes the condition of social solidarity in the farming community, this research also has the opportunity to become an empowerment model for the farming community going forward. The purpose of this study is to describe a.) The form of strengthening the solidarity of the onion farmers community in Serading Village, Moyo Hilir District, and describing what factors support the strengthening of the solidarity of the farming community. This type of research is qualitative with ethnographic design. The research site is in Serading Village, Moyo Hilir District, Sumbawa Regency. The time of the study is from January to May 2020. The research subject is a community of farmers from Bima who work at the research location. Data collection techniques using observation, interviews and documentation. Data validity uses source triangulation. Data analysis techniques with data collection, data reduction, data presentation, and conclusions. The form of strengthening that occurs in the social solidarity of the farming community in Serading Village, namely: a.) Mutual cooperation and b.) Cooperation (individuals with individuals or groups with groups). The factors that strengthen social solidarity in Serading Village include: a.) Economic factors where the motives of social solidarity that arise are mostly in the form of efforts to improve the economic level of farmers; b.) Religious Factors, the majority of farmers in Serading Village are Muslim. although the majority of farmers in Serading Village are migrants from various other regions, finding farmers who have a religion other than Islam is difficult; c.) Cultural factors, interesting from the findings of the field, the majority of cultivating 
Terakreditasi Peringkat 5 (No. SK: 85/M/KPT/2020)

farmers in Serading village came from Bima . One factor is that there are cultural similarities (both in shape and cultural value) between the Bima community and the Sumbawa community.

\section{Keywords : Strengthening, Social Solidarity, Community of Farmers}

\section{PENDAHULUAN}

Manusia adalah mahluk yang diciptakan Tuhan untuk mengatur tatanan kehidupanya di muka bumi ini. Perkembangan kehidupan manusia awal jumlahnya sangat kecil dan kenginan- kenginan yang relative sederhana. Ketika proses itu berjalan terusmenerus mengakibatkan populasinya bertambah dan juga membawa berbagai macam persoalan. Berkurang atau bertambahnya penduduk disuatu daerah mempunyai hubungan yang erat dengan perkembangan teknologi yang dimiliki oleh golongan penduduk, semakin luas kemungkinan memperbesar hasil-hasil produksi kebutuhan hidup dan semakin luas pula mata pencaharian untuk pertambahan penduduk.setiap pendapatan baru dalam teknologi sangatlah besar pengaruhnya terhadap perkembangan penduduk.

Untuk mewujudkan masayarakat yang sejahtera, adil dan makmur baik materiil maupun spiritual, pemerintah telah melakukan berbagai usaha pembangunan diberbagai bidang. Dari tahun ketahun kegiatan pembangunan yang dilakukan oleh pemerintah maupun swasta telah membuahkan hasil yang memggembirakan seperti yang kita rasakan saat ini yang ditandai dengan peningkatan kesejahteraan hidup.

Namun demikian, peningkatan kesejahteraan hidup tersebut belum dirasakan oleh seluruh masyarakat Indonesia. Hal itu, tercermin sampai sekarang ini masih banyak penduduk Indonesia masih hidup dibawa garis kemiskinan. Hal itu menjadi tugas kita untuk mengentaskan mereka dari kemiskinan dengan berbagai upaya. Penduduk yang miskin tersebut pada umumnya banyak terdapat diperkotaan maupun pedesaan di seluruh Indonesia. Kemiskinan tersebut pada umumnya ditandai oleh ketidak bekerjaan seseorang pada usia kerja karena sulitnya mendapatkan pekerjaan atau karena pemutusan hubungan kerja akibat krisis ekonomi yang terjadi.

Selain perhatian pemerintah masyarakat juga harus berperan aktif dalam menjawab berbagai persoalan dalam kehidupan. Masyarakat yang memiliki solidaritas yang begitu kuat sangat nampak di antara petani bawang merah, jika di antara petani bawang merah ada yang mengalami kesulitan maka rekan-rekan sesama komunitas petani bawang merah merasa terpanggil untuk membantu rekan-rekannya yang mengalami kesulitan atau terkena musibah dalam menjalankan aktivitasnya sebagai petani bawang merah. Rasa solidaritas inilah yang menjadi kekuatan paling kuat untuk mencapai tujuan bersama. Diharapkan dari penelitian ini dapat menjelaskan beberapa masalah berikut;

a. Bentuk penguatan solidaritas komunitas petani bawang merah di Desa Serading Kecamatan Moyo Hilir

b. Faktor-faktor apakah yang mendukung penguatan solidaritas komunitas petani bawang merah di Desa Serading Kecamatan Moyo Hilir

\section{KAJIAN PUSTAKA}

\section{Hakikat Masyarakat}

Pembangunan manusia dan pembangunan masyarakat satu sama lain saling berkaitan. Manusia secara kodrat mempunyai kecenderungan hidup bermasyarakat sesuai kedudukannya sebagai mahluk hidup dan mahluk sosial.

Kehidupan manusia terdiri atas individu, kelompok dan komunitas yang melakukan interaksi dan komunikasi satu sama lain baik secara terorgansasai maupun tidak untuk mencapai tujuan bersama dalam berbagai kebutuhan hidup. Semua aspek 
pembangunan ditujukan kepada masyarakat sebagai metode mempunyai karakteristik sendiri. Pengertian masyarakat menurut beberapa ahli:
a. Ralp
Linton
(Soerjono

Soekanto,2006:22) Masyarakat adalah sekelompok manusia yang telah cukup lama dan bekerja sama, sehingga mereka itu dapat mengorganisasikan dirinya sebagai salah satu kesatuan sosial dengan batas ternetu. Pengertian ini menunjukkan adanya syarat-syarat sehingga disebut masyarakat, yakni adanya pengalaman hidup bersama dalam jangka waktu cukup lama dan adanaya kerjasama diantara anggota kelompok, memiliki pikiran atau perasaan menjadi bagian dari satu kesatuan kelompoknya. Pengalaman hidup bersama menimbulkan kerjasama, adaptasi terhadap organisasi dan pola tingkah laku anggota-amggota. Faktor waktu memegang peranan penting, sebab setelah hidup bersama dalam waktu cukup lama, maka terjadi proses adaptasi terhadap organisasi tingkah laku serta kesadaran berkelompok.

b. Arbi dan Syahrun (Eddy Tukijan, dkk 2009:4) masyarakat adalah kelompok individu yang berintegrasi secara terorganisasi yang mengikuti suatu cara tertentu Jadi dapat disimpulkan bahwa masyarakat adalah kesatuan hidup manusia yang berinteraksi sesuai dengan sistem adat- istiadat tertentu yang sifatnya berkesinambungan dan memiliki rasa identitas bersama.

\section{Interaksi Sosial}

Salah satu sifat manusia adalah kenginan untuk hidup bersama dengan manusia lainnya.dalam hidup bersama anatara msnusia dan manusia dan manusia atau manusia dan kelomppok tersebut terjadi "hubungan" dalam rangka memenuhi kebutuhan gidupnya. Melalui hubungan itu manusia ingin menyampaikan maksud, tujuan dan keinginannya masing-masing. Sedangkan untuk mencapai keinginan itu harus diwujudkan dengan tindakan melalui hubungan timbale balik. Hubungan inilah yang disebut interaksi. Interaksi terjadi apabila satu individu melakukan tindakan sehingga menimbulkan reaksi dari individu-individu yang lain. Karena itu, interaksi terjadi dalam suatu kehidupan sosial.

a. Solidaritas Sosial

Secara etimologi arti solidaritas adalah kesetiaan atau kekompakan. Dalam bahasa arab berarti tadhamun (ketetapan dalam hubungan) atau takaful (saling menyempurnakan/melindungi). Pendapat lain mengemukakan bahwa solidaritas adalah kombinasi atau persetujuan dari seluru elemen atau individu sebagai sebuah kelompok. Dalam kamus besar bahasa Indonesia dijelaskan bahwa solidaritas di ambil dari kata solider yang berarti mempunyai atau memperlihatkan perasaan bersatu.

Dengan demikian, bila dikaitkan dengan kelompok sosial dapat disimpulkan bahwa solidaritas adalah rasa kebersamaan dalam suatu kelompok tertentu yang menyangkut tentang kesetiakawanan dalam mencapai tujuan dan keinginan yang sama. Wacana solidaritas bersifat keanusian dan mengandung nilai adiluhung (mulia/tinggi), tidaklah aneh kalau solidaritas ini merupakan keharusan yang tidak bisa ditawar-tawar lagi. Memang mudah mengucapkan kata solidaritas tetapi kenyataannya dalam kehidupan manusia sangat jauh sekali. Dalam ajaran islam solidaritas sangat ditekankan karena solidaritas salah satu bagian dari nilai islam yang mengandung nilai kemanusiaan.

Solidaritas dapat pula diartikan sebagai rasa kebersamaan, rasa kesatuan kepentingan, rasa simpati, sebagai salah satu anggota dari kelas yang sama. Atau bisa diartikan perasaan atau ungkapan dalam sebuah kelompok yang dibentuk 
Jurnal Ilmu Sosial dan Pendidikan

http://ejournal.mandalanursa.org/index.php/JISIP/index

Terakreditasi Peringkat 5 (No. SK: 85/M/KPT/2020)

oleh kepentingan bersama. Teori solidaritas Menurut Emile Durkheim, solidaritas sosial merupakan kesetiakawanan diantara individu atau kelompok dalam kehidupan bersama. Konsep solidaritas sosial sebagai keadaan yang menunjuk kepada suatu hubungan individu atau kelompok yang didasarkan pada perasaan moral dan kepercayaan yang dianut bersama dan diperkuat oleh pengalaman emosional yang sama. Dalam solidaritas sosial, kebersaman dan kepercayaan menjadi unsure utama yang membentuk integrasi sosial bukan hubungan yang brdasarkan kontrak yang dibuat oleh persetujuan rasional.

b. Hakikat Komunitas

Istilah komunitas berasal dari bahasa latin yaitu communitas yang berasal dari kata dasar communis yang artinya masyarakat, publik atau orang banyak. Komunitas juga dapat didefenisikan sebagai kelompok khusus dari orang-orang yang tinggal dalam wilayah tertentu, memilii kebudayaan dan gaya hidup yang sama, sadar sebgai satu kesatuan dan dapat bertindak secara kolektif dalam usaha mereka mencapai suatu tujuan.

Pengertian komunitas menurut beberapa ahli yaitu:

1.) Menurut Kertajaya Hermawan (2008), Komunitas adalah sekelompok orang yang saling peduli satu sama lain lebih dari yang seharusnya, dimana dalam sebuah komunitas terjadi relasi pribadi yang erat antar para anggota komunitas tersebut karena adanya kesamaan interest atau values.

2.) Wikipedia bahasa Indonesia menjelaskan komunitas sebagai sebuah kelompok sosial dari beberapa organisme yang berbagi lingkungan umumnya memiliki ketertarikan dan habitat yang sama. Dalam komunitas
Vol. 4. No. 3 Juli 2020

p-ISSN: 2598-9944 e-ISSN: 2656-753

manusia, individu-individu di dalamnya dapat memiliki maksud, kepercayaan, sumber daya, preferensi, kebutuhan, risiko dan sejumlah kondisi lain yang serupa.

Jadi, dapat disimpulkan bahwa komunitas adalah suatu kumpulan orangorang tertentu pada suatu wilayah tertentu dan waktu tertentu yang membentuk kelompok-kelompok sosial, yang kemudian menghasikan kebudayaan dan peraturan-peraturan yang dijadikan dasar bersama, serta dapat bertindak secara kolektif dalam mencapai tujuan yang sama.

c. Hakikat Petani

Petani di Indonesia mayoritas merupakan petani kecil dengan penguasaan dan pengusahaan lahan yang relatif sempit. Keterbatasa tersebut pada dasarnya bercirikan antara lain:

1.) sangat terbatasnya penguasaan terhadap sumberdaya,

2.) sangat menggantungkan hidupnya pada usaha tani,

3.) tingkat pendidikan yang relatif rendah dan

4.) secara ekonomi, mereka tergolong miskin (Singh, 2002).

Terdapat bermacam-macam defenisi yang menjelaskan pengertian tentang petani. Defenisi-defenisi tersebut pada dasarnya mengacu pada sistem kehidupan petani yang mengarah pada sifat subsistem, artinya masyarakat dengan tingkat hidup yang minimal atau hanya sekedar untuk hidup. Defenisi petani menurut para ahli:

1.) Menurut Poerdarminta (1995:23) mendefinisikan petani sebagai orang yang bermata pencaharian dengan bercocok tanam di tanah.

2) Menurut Wolf (1985), mengkaji petani secara antropologis atau historis, dari manusia primitif hingga menjadi petani modern.

3.) Menurut Rodjak (2002) Petani adalah 
orang yang melakukan kegiatan bercocok tanam hasil bumi atau memelihara ternak dengan tujuan untuk memperoleh kehidupan dari kegiatannya itu. Petani sebagai pengelola usahatani berarti ia harus mengambil berbagai keputusan di dalam memanfaatkan lahan yang dimiliki untuk kesejahteraan hidup keluarga.

4.) Menurut Selo Soemardjan dalam Mubyarto (1987 : 65), mengatakan bahwa yang dimaksud petani adalah kuli (kenceng/kendo) yang berarti pemilik tanah dengan segala kewajiban dan bebannya. Petani adalah seseorang yang mengendalikan secara efektif sebidang tanah yang dia sendiri sudah lama terikat oleh ikatanikatan tradisi.

Jadi dapat disimpulkan bahwa petani adalah orang yang menggantungkan hidupnya pada lahan pertanian sebagai mata pencaharian utamanya.

\section{METODE PENELITIAN}

\section{Jenis Penelitian}

Metode yang digunakan dalam penelitian ini adalah metode penelitian deskriptif kualitatif. Metode penelitian kualitatif adalah penelitian yang bermaksud memahami fenomena tentang apa yang dialami oleh subjek penelitian misalnya perilaku, persepsi, motivasi, tindakan, dan lain-lain. Secara holistik dan dengan cara deskripsi dalam bentuk kata-kata dan bahasa, pada suatu konteks khusus yang alami dan memanfaatkan metode alamiah. Sehingga dalam penelitian ini akan dideskripsikan proses menguatnya solidaritas sosial komunitas petani bawang di Serading, dan faktor-faktor pendorong komunitas petani bawang di serading menjadi lebih kuat.

\section{Waktu dan Lokasi Penelitian}

Penelitian ini dilaksanakan di desa Serading kecamatan moyo hilir, yang dilaksanakan selama sepuluh bulan.

\section{Populasi dan Teknik Sampling}

a. Populasi

Populasi atau Universe adalah jumlah keseluruhan dari unit analisis (Slamet, 2006:40). Populasi merupakan jumlah tertentu dari individu yang akan diselidiki oleh peneliti. Populasi dalam penelitian ini adalah semua petani bawang yang ada di Desa Serading Kecamatan Moyo Hilir Kabupaten Sumbawa - NTB.

b. Sampling

Sampel yang diambil dari populasi dalam penelitian ini bukan sesuatu yang mutlak. Artinya sampel yang akan diambil menyesuaikan dengan kebutuhan di lapangan. Dalam penelitian ini sampel berfungsi menggali beragam informasi dan menemukan informasi penting. Jumlah sampel penelitian ini sebanyak 8 orang, diambil menggunakan teknik purposive sampling atau sampling bertujuan.

Sampel diambil berdasarkan tiga pertimbangan (1) Jenis kepemilikan Tanah (petani penggarap atau petani pemilik tanah), dan (2) Suku atau daerah asal petani Bawang di desa Serading. Berikut tabel sampling dalam penelitian ini:

Tabel Teknik Sampling

\begin{tabular}{|c|c|c|}
\hline $\begin{array}{l}\text { Keppemiliknu Tanahl Sulku atau } \\
\text { dherahh asal petani }\end{array}$ & Dari des Sending & $\begin{array}{l}\text { Dari dheenh hin luar } \\
\text { Sernding }\end{array}$ \\
\hline Tanah milikik pribadi & 2orang & 2 orang \\
\hline Tanal serta & 2 orang & 2 orang \\
\hline
\end{tabular}

\section{Teknik Pengumpulan Data}

Teknik pengumpulan data yang dilakukan memanfaatkan beberapa media, diantaranya:

1. Observasi

2. Wawancara (Intreview)

3. Dokumentasi 
Jurnal Ilmu Sosial dan Pendidikan

http://ejournal.mandalanursa.org/index.php/JISIP/index

Terakreditasi Peringkat 5 (No. SK: 85/M/KPT/2020)

\section{Validitas Data}

Penelitian ini menggunakan triangulasi untuk mencapai validitas data. Teknik triangulasi adalah teknik penarikan keabsahan data dengan keperluan penyelesaian atau sebagai pembanding terhadap data yang sudah ada. Penelitian ini menggunakan triangulasi sumber, sehingga peneliti membandingkan dan mengecek kembali derajat kepercayaan suatu sumber informasi yang diperoleh melalui waktu dan alat yang berbeda dalam metode kualitatif. Trianggulasi sumber dalam penelitian ini diambil dari dua sumber, sehingga pada penelitian ini diambil dua informan untuk masing-masing sampel penelitian untuk menguji validitas data dari klasifikasi sampel yang diambil..

\section{Teknik Analisis Data}

Sesuai dengan teknik pengumpulan data tersebut maka analisanya berkembang dan berjalan serta berlangsung proses di saat pengumpulan data dilakukan. Peneliti bekerja dengan teknik analisa data interactive of analysis yang mempunyai tahap-tahap sebagai berikut :

\section{Bagan Komponen dalam Analis Data (Interactive Model)}

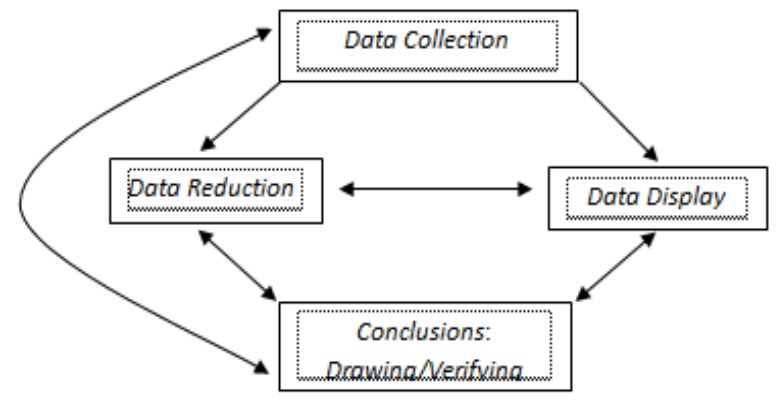

\section{HASIL DAN PEMBAHASAN}

\section{Bentuk Penguatan Solidaritas Sosial}

Penguatan dalam penelitian ini bermakna pemberdayaan, sehingga menguatkan aspek aspek solidaritas sosial diantara komunitas petani akan berdampak positif bagi perkembangan komunitas petani. Dampak positif tersebut bisa berupa perbaikan hasil pertanian atau lebih jauh lagi adalah perbaikan ekonomi petani. Hal inilah yang menjadi alasan peneliti memilih penelitian kualitatif, disamping hasil riset ini mendeskripsikan kondisi solidaritas sosial dalam komunitas petani, penelitian ini berpeluang pula menjadi model pemberdayaan untuk komunitas petani ke depannya.

Di era milenial seperti saat ini, percepatan informasi dan komunikasi semakin pesat, sulit bagi petani tradisional untuk bersaing dengan sector lain diluar pertanian, sehingga dengan solidaritas sosial diharapkan tercipta transfer of knowledge antara petani modern dengan petani tradisional. Mekanisme sedarhana yang ingin diciptakan dari penelitian ini adalah petani tradisional menyumbangkan aspek-aspek moral dalam kerangka solidaritas sosial sedang petani modern menyumbangkan aspek-aspek teknologi dan Informasi kepada petani tradisional.

a) Gotong royong

Gotong royong umumnya dimaknai sebagai mengerjakan sesuatu secara bersama-sama dan atas dasar suka rela dengan tujuan melancarkan atau meringankan pekerjaan tersebut. Makna yang umum dipahami tersebut tidak menunjukan sama sekali manfaat atau nilai materil dari hasil dari kerja suka rela tersebut. Padahal kalau dilihat dari asas kepentingan dan manfaat, gotong royong sangat kental akan manfaat kolektif dalam suatu kelompok sosial.

Demikian pula halnya dengan komunitas petani bawang di Desa Serading, disaat melakukan pengeboran air dan pembuatan jalur irigari untuk kepentingan pengairan dilakukan dengan gotong royong. Gotong royong dalam bentuk ini dilakukan dengan harapan mendapatkan manfaat kolektif dalam komunitas petani yaitu mengairi lahan tiap-tiap anggota komunitas.

Dari gotong royong yang dilakukan oleh petani bawang di Desa Serading bisa dilihat bagaimana posisi 
individu sebagai bagian dari kelompok. Posisi pertama adalah peran individu untuk kepentingan kelompok dan yang kedua adalah manfaat yang diberikan kelompok bagi individu.

b) Kerja Sama (individu dengan individu atau kelompok dengan kelompok).

Bagian kedua dari solidaritas sosial ditemukan pada petani bawang di Desa Serading adalah Kerja sama. sekilas kerja sama mirip dengan gotong royong, namun pada kajian ini sengaja dipisah untuk membedakan antara manfaat kolektif dan manfaat individu yang diperoleh. Bentuk kerja sama yang ditemukan pertama adalah Pinjam modal dan bagi hasil. Dimana seorang petani tidak harus memiliki uang banyak untuk mencukupi modal dalam bertani, anggota kelompok memiliki prioritas membantu sesamanya yang memerlukan modal dimasa tanam. Sistem ini membantu petani terhindar dari jebakan uang para rentenir. Bahkan ketika hasil patungan pun belum mencukupi, anggota kelompok lain tidak segan untuk mencarikan modal dari keluarga jauhnya. (kerja sama individu dengan individu)

Bentuk kerja sama yang ditemukan kedua adalah kerjasama Kelompok orang Bima yang sudah lama menetap di Sumbawa bekerjasama dengan kelompok petani Bima yang menggarap lahan di Sumbawa. Kerjasama ini berupa kerjasama kelompok dimana kedua kelompok ini dibagi berdasarkan perannya. Orang Bima yang sudah lama menetap di Sumbawa memberikan akses-akses untuk membantu saudara-saudaranya sesama suku yang mencari nafkah di perantauan. Hal ini menunjukan adanya solidaritas mekanik dari kelompok ini dimana nilai-nilai primordial melekat didalamnya.

\section{Faktor - faktor penguat solidaritas sosial}

a) Faktor Ekonomi

Penelitian ini membahas solidaritas yang berlangsung pada komunitas petani. Konsekuensi logisnya motif-motif dari solidaritas sosial yang muncul kebanyakan berupa usaha peningkatan taraf ekonomi petani. Perasaan senasib dari masing-masing anggota yang merasa perlu untuk meningkatkan taraf ekonomi memunculkan kesadaran kolektif untuk senantiasa saling membantu. Dari bentuk-bentuk solidaritas sosial yang ditemukan bisa dilihat bagaimana pergeseran dari solidaritas mekanik menuju solidaritas organik. Mula mula yang kita temukan adalah nilai-nilai moral semacam kebersamaan, persatuan, dan primordial, namun lambat laun saat masing masing anggota komunitas petani merasakan manfaat materilnya.

b) Faktor Agama

Mayoritas masyarakat NTB memeluk agama Islam, begitu pula di Sumbawa. Mayoritas petani di desa Serading baik itu petani penggarap maupun petani pemilik lahan beragama Islam. Dalam doktrin agama Islam dikenal istilah ikhwanul muslimin yang berarti saudara sesama muslim (sesama Islam). Dimana dalam Islam diajarkan dalam Al Quran surat Al Hujurat "Orang-orang beriman itu sesungguhnya bersaudara. Sebab itu damaikanlah (perbaikilah hubungan) antara kedua saudaramu itu dan takutlah terhadap Allah, supaya kamu mendapat rahmat". (QS Al Hujurat: 10).

Selain itu, ada banyak lagi ajaran islam yang mengajarkan untuk bersatu. Ayat lain yang membuat faktor agama ini menjadi salah satu bagian penting dalam menguatkan solidaritas sosial adalah Al Quran surat Al-Ma'idah yang berbunyi: "dan tolong-menolonglah 
kamu dalam (mengerjakan) kebajikan dan takwa, dan jangan tolongmenolong dalam berbuat dosa dan pelanggaran. Dan bertakwalah kamu kepada Allah, sesungguhnya Allah amat berat siksa-Nya". (Surat Al-Ma'idah 2)

Petani di Desa Serading mayoritas beragama Islam. meskipun mayoritas petani di Desa Serading merupakan pendatang dari berbagai daerah lain, namun menemukan petani penggarap yang beragama lain selain Islam menjadi hal yang sulit. Ini menunjukan bagaimana faktor agama mempengaruhi penguatan solidaritas sosial di daerah ini. Dibeberapa daerah lain di wilayah Sumbawa ditemukan petani petani penggarap yang beragama lain namun beda halnya dengan di lokasi penelitian kami yang sama sekali tidak ada.

\section{c) Faktor Budaya,}

Menarik dari temuan lapangan, Mayoritas petani penggarap di desa Serading berasal dari Bima . Salah faktornya adalah Ada kemiripan budaya (baik bentuknya maupun nilai budayanya) antara masayarakat Bima dan masyarakat Sumbawa, meski memiliki bahasa yang berbeda. Kemiripan nilai budaya ini membuat petani asal Bima lebih mudah beradaptasi dengan masyarakat Sumbawa dibandingkan dengan yang berasal dari daerah lain. Hal ini bisa juga dilihat dari sudah banyak terjadi perkawinan / pernikahan antara orang orang Bima dengan orang orang Sumbawa

Budaya merupakan faktor pendorong penguatan solidaritas sosial yang menarik, kristalisasi nilai nilai dan moral dalam masyarakat seperti nilai nilai agama membuatnya sulit untuk dibedakan dengan nilai nilai asalnya. Sehingga untuk kepentingan klasifikasi pada tulisan ini nilai nilai budaya yang diambil adalah nilai budaya yang tertuang dalam filosofi hidup masyarakat Sumbawa yang sudah umum dikenal di seluruh wilayah Sumbawa.

Pertama, Sabalong samalewa yang artinya dunia material dan spiritual yang berusaha dibangun secara selaras dan berimbang. Sederhananya sabalong samalewa berati keseimbangan dunia dan Akhirat.

Sejalan dengan filosofi masyarakat Sumbawa tersebut masyarakat Bima juga memiliki filosofi hidup yang serupa, yaitu Maja labo dahu yang secara kharfiah artinya malu dan takut. Malu bermakna malu untuk berbuat hal-hal yang melanggar aturan, nilai dan norma dalam masyarakat. Sedangkan takut bermakna takut pada balasan atau ganjaran dari perbuatan-perbuatan buruk yang dilakukan, takut dalam filosofi masyarakat Bima cenderung merujuk pada takut pada Allah SWT. Dari makna maja labo dahu kita bisa melihat dimensi Maja (malu) yang berdimensi lahiriah (material) dan takut yang berdiimensi batiniyah (spiritual).

Kedua, adat berenti $k o$ syara, syara barenti ko kitabullah ungkapan ini memiliki makna filosofis bahwa aturan, nilai dan norma adat yang ada dalam masyarakat Sumbawa sejatinya harus sejalan dengan syariat Islam yang tertuang dalam Al Quran dan Al Hadist (sebagai kitab suci umat Islam)

Dalam masyarakat Bima filosofi semacam ini juga sering dituangkan dalam ungkapan "adat bersendikan sara, sara bersendikan kitabullah"yang maknanya persis dengan "adat berenti ko syara, syara barenti ko kitabullah" Dari dua nilai filosofi ini bisa kita rasakan nilai budaya tersebut merupakan kristalisasi nilai-nilai agama 
Islam yang telah lama tumbuh dan berkembang dalam masyarakat.

\section{Kesimpulan}

Penguatan dalam penelitian ini bermakna pemberdayaan, sehingga menguatkan aspek aspek solidaritas sosial diantara komunitas petani akan berdampak positif bagi perkembangan komunitas petani. Dampak positif tersebut bisa berupa perbaikan hasil pertanian atau lebih jauh lagi adalah perbaikan ekonomi petani. Hal inilah yang menjadi alasan peneliti memilih penelitian kualitatif, disamping hasil riset ini mendeskripsikan kondisi solidaritas sosial dalam komunitas petani, penelitian ini berpeluang pula menjadi model pemberdayaan untuk komunitas petani ke depannya. Adapun bentuk penguatan yang terjadi dalam solidaritas sosial komunitas petani di Desa Serading, yaitu: a.) Gotong royong dan b.) Kerja sama (individu dengan individu atau kelompok dengan kelompok).

Adapun faktor - faktor penguat solidaritas sosial di Desa serading diantaranya: a.) Faktor ekonomi dimana motif-motif dari solidaritas sosial yang muncul kebanyakan berupa usaha peningkatan taraf ekonomi petani; b.) Faktor Agama, Petani di Desa Serading mayoritas beragama Islam. meskipun mayoritas petani di Desa Serading merupakan pendatang dari berbagai daerah lain, namun menemukan petani penggarap yang beragama lain selain Islam menjadi hal yang sulit; c.) Faktor Budaya, menarik dari temuan lapangan, Mayoritas petani penggarap di desa Serading berasal dari Bima. Salah faktornya adalah Ada kemiripan budaya (baik bentuknya maupun nilai budayanya) antara masayarakat Bima dan masyarakat Sumbawa.

\section{Ucapan Terima Kasih:}

Dengan terlaksananya penelitian ini tidak lupa kami selaku tim peneliti mengucapkan terima kasih kepada Kementerian Pendidikan dan Kebudayaan (Kemendikbud) Lembaga Layanan Pendidikan Tinggi Wilayah VIII (Bali - Nusa Tenggara) (LLDIKTI-VIII) atas pemberian dana penelitian, sehingga penelitian ini bisa terlaksana sesuai dengan waktu yang ditetapkan.

\section{DAFTAR PUSTAKA}

Basrowi, 2005, Pengantar Sosiologi, Ghalia Indonesia:Bogor.

Borut Fitriani, 2012. Makalah Antropologi Masyarakat Peasent. Ambon: http//blogspot.com/2012/02/makalahantropologi-masyarakat-peasent/.

Durkheim Emile. 2011. Solidaritas mekanik dan solidaritas organik. [online] tersedia :http/blogspot. Com/2011/05/solidaritasmekanik-dan-solidaritas organic/.

Isbandi Rukminto, 2008. Intervensi Komunitas (pengembangan masyarakat sebagai upaya pemberdayaan masyarakat). Jakarta : Raja Grafindo Persada.

Johnson, Paul. Doyle. 1986. Teori sosiologi klasik dan modern, Jakarta:pt gramedia.

Jurdi, Syarifuddin, Islam, Masyarakat Madani Dan Demokrasi Di Bima : Membangun Demokrasi Kultural Yang Berbasis Religius, Yogyakarta: CNBS, 2007, hlm. 116

Koentjaraningrat, 2009. Pengantar Ilmu Sosiologi, edisi revisi. Jakarta: Rineka Cipta

Nawawi. 1991. Penelitian Bidang Sosial. Yogyakarta:Gajahmadah University Press

Poerdarminta. (1995). Kamus Umum Bahasa Indonesia, Jakarta:Balai Pustaka

R. M. Lubis, 2012. Wujudkan Enrekanng sebagai penangkar bibit bawang. Enrekang http/ blogspot. Com/2012/06/wujudkan-Enrekangsebagai-penangkar-bibit-bawang/.

RahmawatiAnnisaa,2012.KomunitasSosiologi Pertanian.http://blog.ub.ac.id/annisaarah mawati/2012/04/komunitas-sosiologipertanian/

Rodjak.2006.Manajeman Usaha Tani.Pustaka Gitaguna Bandung

Setiadi Elly M. Dkk. 2006. Ilmu Sosial Budaya Dasar, edisi ketiga. 
Terakreditasi Peringkat 5 (No. SK: 85/M/KPT/2020)

Jakarta:Kencana Prenadamedia Group.

Soekanto Soerjono, 2006. Sosiologi Sebagai

Pengantar. Jakarta: Rajawali Pers.

Syani abdul. 1987. Sosiologi kelompok dan masalah sosial. Jakarta: fajar agung.

Tukijan Eddy, dkk. 2009. Sosiologi

Pendidikan. Jakarta : Departemen Pendidikan Nasional.

Wolf Erik.1983. Petani suatu Tinjauan Antropologi.CV Rajawali Jakarta 